International Journal of Social Science And Human Research

ISSN(print): 2644-0679, ISSN(online): 2644-0695

Volume 04 Issue 12 December 2021

DOI: 10.47191/ijsshr/v4-i12-42, Impact factor-5.586

Page No: 3766-3767

\title{
Research of Samarkand State University on Central Sughd Monuments
}

\section{Yoo In Young}

Doctoral student, Department of Archeology, Samarkand State University Uzbekistan

\begin{abstract}
Sogdia is one of the oldest cultural centers not only in Uzbekistan but also in Central Asia. The development of the history of the oasis is extremely rich in historical and cultural monuments of different stages of development. We have recognized the richness of historical and cultural monuments of Zarafshan and Kashkadarya oasis because of archeological excavations in the region. The article deals with the archeological excavations carried out by researchers of the Samarkand Institute of Archeology and researchers of Samarkand State University in the early medieval monuments of Central Sughd.
\end{abstract}

KEYWORDS: Central Sughd, Early Middle Ages, Kofirqala, Kuldortepa, handicrafts, trade, urban planning, rural architecture, Rivdod.

\section{INTRODUCTION}

The Department of Archeology of Samarkand State University is one of the first in Central Asia. In 1971, the Department of Archeology of Samarkand State University was established. Scientists of the department conduct research on the general topic "Early civilizations in the territory of Uzbekistan: material and spiritual culture." The department also has a museum laboratory, which helps conduct archaeological research. The materials collected here since 1947 shed light on the history of the material culture of the two rivers of Central Asia. Recent research has led to the study of tangible cultural heritage sites that provide important historical information. Scientists of the department are studying several medieval urban and rural areas of Central Sughd.

Sughd is one of the largest cultural centers in Central Asia, and archeological research has shown that urban culture in the region dates back to the Early Iron Age. The influence of the central city allowed the formation of rural and urban culture in areas suitable for agriculture.

\section{MAIN PART}

Because of joint research of scientists of the Samarkand Institute of Archeology and professors and students at Samarkand State University in the early medieval cities of Kofirqala and Kuldortepa in the south-west of Central Sughd, as well as in rural settlements such as Rabodtepa II. At that time, new information was obtained about the first medieval urban planning, rural architecture of central Sughd.

In particular, the Kafirqala monument is located on the left bank of the Dargam Canal, $18 \mathrm{~km}$ south of the ancient city of Afrosiab and $50 \mathrm{~km}$ west of the ruins of Panjikent. Excavations at the monument's arch show that a luxurious terraced palace with raised walls made of cotton and raw bricks has been opened here, and the room is covered with baked bricks. Remains of burnt wooden panels decorated on the floor of the room testify to the widespread use of wood carvings. Pottery sprinkled with mica, copper and silver coins, and about 900 handmade clay bulls were also seized from the monument. We know that the pottery mentioned in Kafirqala is very elegant in its own way, just like the pottery made of gold and silver. It can be concluded that Kafirqala was also a political center in the early Middle Ages, an area where handicrafts and trade flourished. At the same time, we can assume that such a large economic and political center was located in the place of Rivdod, which is mentioned in written sources.

The Kuldortepa monument is located in the village of Bakhrin, Urgut district, with a total area of 17 hectares. The city, like many other cities in Central Asia, is divided into three parts: the Ark, the Shahristan, and the Rabot. The main center of the city was its arch. In July 2018, in collaboration with researchers from the Institute of Archaeological Research and professors of Samarkand State University, excavations were carried out on the defensive wall on the south side of the monument. This defensive wall belongs to two construction periods, during the first construction period it was raised on the cotton platform with $35 \times 35 \times 10$ $11 \mathrm{~cm}$ of raw bricks, and during the second construction period, the $44 \times 44 \times 11-12 \mathrm{~cm}$ wall on the cotton platform was built during 


\section{Research of Samarkand State University on Central Sughd Monuments}

the first construction period. He built the outside of the wall. These construction periods date back to antiquity, and it was found that in the early and advanced Middle Ages, these defensive walls, which were $7 \mathrm{~m}$ high, were used.

The Rabodtepa I monument is located in the territory of Kalduvoyjar MFY, Urgut district, Samarkand region. The walls of these rooms were made of cotton blocks, and raw bricks were laid on top of them, and the roofs were covered with arches.

Archaeological excavations at Kofirqala, Kuldortepa, and Rabodtepa, have revealed that the entrance doors and windows of all the rooms are arched. Doors closed in this way were common in Central Asian monuments in the early Middle Ages [1]. We built the doors of the room in or near the corner of the wall. Of course, this followed the law of non-reduction of the room area. In addition, the doors also serve as lighting fixtures for the rooms [2]. We built the exterior doors with wind direction and sunlight in them.

V.L. Voronina noted we did not replace the interior doors of the rooms with wooden doors, and we carpeted the doors of the monumental houses or opened them. Only wooden doors are installed at the entrances and exits, in the lobby rooms. The twotiered doors are mainly recorded at the monument in Panjikent [3]. In Kofirqala, Kuldortepa, and Rabodtepa I monuments, in the south-eastern part of Central Sogd, the doors and their frames have not been preserved, but the sleeping traces of the boxes, burnt wood marks, and pits in the threshold used wooden doors. The doors are 70-1.20 m wide and we made the arches in two different ways. It divided the arch structure of the arches into axial and convex types. We made the doors of wood. Yu.Ya. Yakubov noted the door structures in folk architecture have remained unchanged since the early Middle Ages.

The roofs of the rooms are mainly covered in two ways - domed and flat. In the first method, narrow corridors and small khans' roofs were laid in four or eight rows on a brick wall, and covered with a dome. The second method is used to cover the roofs of large rooms.

Depending on the shape of the domes, kurra (hemisphere), continental (segment), maxrut (base pyramid or polygonal cone), odd (spheroconic), turkistoni (base cylindrical cone), saganaposh (saganasimon)), balkhi (basically a rectangle), charkhi (basically a circle), turnip, mirzoi, zorbalik, chortark, naqbandi, kulokhi and others. In the early medieval architecture of Kofirkala, Kuldortepa and Rabodtepa II, the "Balkhi dome" was widely used to cover the roofs of buildings.

\section{CONCLUSION}

So, in Kofirqala, Kuldortepa is a city in an important branch of Samarkand Sugdi. We can see that the monument had cultural ties with Afrasiyob, Panjikent, Chach, Jizzakh, and Nakhshab in the early Middle Ages, that their pottery is like each other, and that they are close to each other in the culture of construction.

In addition, over 900 bullets found at the monument show the monument is an important political center in the Sughd region.

In conclusion, the members of the department are working hard to enrich and promote our rich cultural heritage.

\section{REFERENCES}

1) Voronina V.L. The architecture of ancient Panjikent. Proceedings of the TAE. Vol. III, MIA, no. 66. 1958 , p. 212.

2) Litvinsky B.A., Soloviev V.S. Medieval culture of Tokharistan. M., 1985. P.60.

3) 3.Nielsen V.A. Formation of feudal architecture in Central Asia (V-VIII centuries). - T., 1966.

4) Grolov A.S. Harmonization and decoration of architectural forms. S., 2003. B.176. 